appeared, in any event, to be rather homogeneous, comprising mainly low brome grass and weeds. It is of interest, however, that there was three times the concentration of dead voles where the field north of the right-ofway was summerfallow than where wheat stubble occurred on both sides.

Since repairs were confined to one side of the highway it was impossible to establish if there was any differential in direction of attempted crossings. Apparently all the voles which encountered the oil died. Two had got free within the measured mile but these were dead in the grass within a foot of the oil strip. Their paths were very easy to follow.

While similar road maintenance work had been conducted elsewhere in the immediate area, no evidence of small mammal mortality was found. In some cases gravelling operations covered the oil completely, leaving no oil strip. Probably most significant was the timing of the operation which resulted in the mortality described. Applied at 7:00 p.m., the oil was probably at its stickiest at the peak of vole evening activity. At the time of examination 17 hours later the oil had "set" sufficiently that it would easily have supported animals of this size.

Thanks are extended to Dr. R. D. Morris who confirmed the identification and sexed the individuals in the sample.

\title{
RECENT ALBERTA POCKET MOUSE RECORDS
}

\section{by Hugh C. Smith, Provincial Museum and Archives of Alberta, Edmonton}

In the list of Alberta mammals several are classified as belonging to the Upper Sonoran Life Zone. Included among these are the Olivebacked Pocket Mouse (Perognathus fasciatus) (Soper, $1964: 39$ ).

The first Alberta records of the Pocket Mouse were obtained in 1951 from extreme southeastern Alberta (Moore, 1952:143). Soper (op. cit.:
175) outlined the northern limit of their range as lying between the Red Deer River and the South Saskatchewan River from Empress on the east to Brooks on the west. Since the earlier work done by Moore there have been no published records for this province. This note is written in order to provide a record of recent specimens collected by museum staff (see Table 1).

\section{Table 1. Recent Alberta Pocket Mouse specimens}

\begin{tabular}{llcll}
\hline Locality & \multicolumn{1}{c}{ Date } & Number & Collector \\
\hline Manyberries & 20 June 1967 & 4 & R. D. Carson \& J. Keizer \\
Hilda & 11 June 1969 & 1 & M. J. Hampson \& H. C. Smith \\
Empress & 24 June 1969 & 2 & M. J. Hampson \& H. C. Smith \\
Empress & 25 June 1969 & 2 & M. J. Hampson \& H. C. Smith \\
Hilda & 26 June 1969 & 3 & M. J. Hampson \& H. C. Smith \\
\hline
\end{tabular}

Nero (1958), who has done considerable work on these rodents in Saskatchewan, found them in a large number of localities in that province, extending their range as far north as Saskatoon. A similar intensive study in Alberta might yield interesting results.

\section{LITERATURE CITED}

Moore, J. G. 1952. Notes on three additions to the rodent fauna of Alberta. Can. Field-Nat., $66: 142-143$.

Nero, R. W. 1958. Additional Pocket Mouse records. Blue Jay, $16: 176-179$.

Soper, J. D. 1964. The mammals of Alberta. The Queen's Printer, Edmonton. 